\title{
Optimization of Struvite Crystallization and Heavy Metal Recovery in Wastewater Using Response Surface Methodology
}

\author{
D. S. PERWITASARI ${ }^{1,3}$, S. MURYANTO ${ }^{2}$, J.JAMARI ${ }^{3}$ and A.P. BAYUSENO ${ }^{3}$ \\ 'Department of Chemical Engineering, Universitas Pembangunan National "Veteran" Jawa Timur, \\ Surabaya 60294 Indonesia. \\ ${ }^{2}$ Department of Chemical Engineering, UNTAG University in Semarang, Bendhan Dhuwur Campus, \\ Semarang 50233, Indonesia. \\ ${ }^{3}$ Department of Mechanical Enginering, Diponegoro University, Tembalang Campus, Semarang \\ 50275, Indonesia. \\ *Corresponding author E-mail: saridyah05@gmail.com, apbayuseno@gmail.com
}

http://dx.doi.org/10.13005/ojc/340136

(Received: September 06, 2017; Accepted: November 25, 2017)

\begin{abstract}
In this study, the recovery of heavy metal $\left(\mathrm{Cu}^{2+}, \mathrm{Pb}^{2+}\right.$, and $\left.\mathrm{Zn}^{2+}\right)$ concentrations and the yield of struvite from MAP precipitation in the wastewater were optimized by SRM (surface response methodology). Struvite was a major mineral precipitated with an impurity of sylvite $(\mathrm{KCl})$ as confirmed by the XRPD Rietveld method, and struvite crystal has a prism-like shape morphology according to the SEM/EDX analysis. The SRM estimates that the concentration of $\mathrm{Pb}^{2+}$ has a significant effect of retarding the yield of the struvite mass, while insignificant effects were related to the $\mathrm{Cu}^{2+}$ and $\mathrm{Zn}^{2+}$ concentration. The optimum yield of struvite was reached at $8.342 \mathrm{mg}$, of which $59.4564 \mathrm{ppm}$ of $\mathrm{Cu}^{2+} 70.7930 \mathrm{ppm}$ of $\mathrm{Pb}^{2+}$ and $77.2114 \mathrm{ppm}$ of $\mathrm{Zn}^{2+}$ could be recovered from wastewater. These optimized conditions could be valuable input data for engineering-design software in an equipment of the effluent treatment plant.
\end{abstract}

Keywords: MAP precipitation, Struvite, Surface response methodology (SRM), Heavy metals, Wastewater treatment

\section{INTRODUCTION}

MAP (Magnesium Ammonium Phosphate) precipitation could occur spontaneously on the surface of process pipes, pumps and other industrial equipment leading to scale deposition of struvite
$\left(\mathrm{MgNH}_{4} \mathrm{PO}_{4} \cdot 6 \mathrm{H}_{2} \mathrm{O}\right)$ minerals ${ }^{1,2}$. The scale deposition of MAP bearing minerals may decrease the performance of equipment and increase the maintenance cost. In contrast, the induced MAP precipitation in the wastewater promotes the beneficial crystallization of struvite, which is

This is an $\mathbf{C}$ Open Access article licensed under a Creative Commons Attribution-NonCommercial-ShareAlike 4.0 International License (https://creativecommons.org/licenses/by-nc-sa/4.0/ ), which permits unrestricted NonCommercial use, distribution and reproduction in any medium, provided the original work is properly cited. 
potentially as fertilizer ${ }^{1}$. Such precipitation technology has been widely implemented in wastewater treatment units for enhancing phosphate $\left(\mathrm{PO}_{4}-\mathrm{P}\right)$ recovery ${ }^{3}$.

In addition to phosphate, the heavy metals and organic pollutants (such as PCB and polycyclic aromatic hydrocarbon) are frequently available in the wastewater, which must be subsequently treated prior to its discharge into the environment. Conversely, their accumulation in the soil becomes a serious problem for sustainable agriculture. Also, strict regulations have been imposed on heavy metal concentrations in fertilizer products. On the other hand, MAP precipitation is known as the best approach to heavy metals and phosphate recovery, which is related to the nucleation and growth of struvite crystals in the solution, whereas desirable amounts of struvite can be precipitated typically through the gravitational settling process ${ }^{1}$.

Further, the conventional removal of toxic heavy metals from wastewaters may involve precipitation, cementation, sedimentation, filtration, coagulation, flotation, complexing, solvent extraction, membrane separation, electrochemical technique, biological process, reverse osmosis, ion exchange and, adsorption ${ }^{4}$. In the precipitation method, heavy metal and phosphate can be recovered by the crystallization of hydroxyl calcium phosphate and magnesium ammonium phosphate. However, the crystallization of hydroxyl calcium phosphate requires a long crystallization induction time and a large amount of seed crystal materials, hence leading to the difficulty for wide application of technology in the recovery of phosphate ${ }^{5}$. Recently, MAP crystallization for phosphate recovery offers its good separation performance, quick response rate, and high phosphorus recovery efficiency. This method is widely applied for phosphate removal from calf manure, leather tanning wastewater, swine wastewater, wasted sludge, industrial wastewater, municipal landfill leachate and poultry manure wastewater ${ }^{5,6,7}$.

MAP crystallization in aqueous solution with a 1:1:1 molar ratio of ions of $\left[\mathrm{Mg}^{2+}\right],\left[\mathrm{NH}_{4}^{+}\right]$and $\left[\mathrm{PO}_{4}^{2}\right]$, can be expressed as the following equation $(1)^{1}$

$\mathrm{Mg}^{2+}+\mathrm{NH}_{4}^{+}+\mathrm{HnPO}_{4}^{\mathrm{n}-3}+6 \mathrm{H}_{2} \mathrm{O} \rightarrow \mathrm{MgNH}_{4} \mathrm{PO}_{4}\left(\mathrm{H}_{2} \mathrm{O}\right)_{6}+\mathrm{nH}^{+}$(1)
The $\mathrm{pH}$ value, supersaturation, the temperature of the wastewater and the presence of metal ions could affect the extent of struvite production and its morphological characteristics ${ }^{3,8,9}$. Specifically, the high heavy metal content makes slower kinetic of the struvite crystallization in term of reduction in value of constant rate ${ }^{6,10}$. While the value of constant rate decreases, the crystal growth also decreases due to the presence of a metal ion inhibitor. For instance, $\mathrm{Zn}$ was reported to the most effective in inhibiting crystal growth ${ }^{8}$. Correspondingly, a low or very low concentration of $\mathrm{Cu}, \mathrm{Pb}$, and $\mathrm{Zn}$ can be adsorbed on struvite surface. Moreover, the more concentrations of metal ions available in the solution make the decrease in the production of struvite ${ }^{8,9,11}$. Accordingly, the possibility of increasing the struvite production eventually requires a compromising stage between optimizing metal removal and the need for increasing phosphorus recovery during crystallization. In such case, the improvement of struvite production could be achieved through better control of process parameters influencing on MAP precipitation for metal recovery in the solution.

Correspondingly, the efficiency of MAP precipitation for recovering heavy metals could be influenced by many process parameters including $\mathrm{pH}$, temperature, time, starting molar ratio, and metal concentration. In this way, multiple variables controlling the removal efficiency could be optimized using an effective method, namely the response surface methodology (RSM). The availability of the experimental design software makes this method in the most efficient way of modifying the experimentation required to optimize many parameters. Here SRM has been successfully used to model and optimize crystallization processes related to wastewater systems ${ }^{2,12}$ and it may be an effective design of the experimental method to optimize struvite production and heavy metal removal from wastewater.

In the SRM approach, the experimental domain (D) could be specified with a number of factors ( $k$-factors), which are represented by independent variables $\left(x_{1}, x_{2}, \ldots . x_{k}\right)$ and a polynomial model could be governed. Correspondingly, designs for an experimental run could be obtained, i.e. sets of experimental conditions, which present the estimates of less variance for coefficients and 
response. The polynomial model, with a $p+1$ coefficient, is given to relating the experimental response to be optimized, $\mathrm{y}$, with the $\mathrm{k}$ factors through the $p$ variables ( $p e^{\prime \prime} k$ ) as shown in Eq.(2).

$Y_{i}=b_{0}+b_{1} x_{1}+b_{2} x_{2}+\ldots+b_{k} x_{k}++b_{11} x_{1}^{2}+b_{22} x_{2}^{2}+\ldots+$ $b_{k k} x_{k}^{2}+b_{12} x_{1} x_{2}+\ldots+b_{1 k} x_{1} x_{k}+\ldots+b_{k-1}{ }^{\prime} x_{k-1} x_{k} x_{1}$

Where $\mathrm{x}_{\mathrm{k}+1}, \mathrm{x}_{\mathrm{k}+2}, \ldots, \mathrm{x}_{\mathrm{p}}$ are the crossproducts and powers of the $\mathrm{k}$ factors,

$\mathrm{x}_{1}, \mathrm{x}_{2} \ldots \mathrm{x}_{\mathrm{k}}$, are the codified factors.

In such method, central composite, Dohelert, and Box Behnken designs are commonly employed in SRM, while the researcher can select the most suitable one for approaching the optimization problem.

The present research was undertaken to optimize MAP precipitation by SRM for struvite production and its effect on the metal ion uptake in wastewater. In this study, the central composite design (CCD) was employed to examine the effects of three metal concentrations $(\mathrm{Cu}, \mathrm{Pb}$, and $\mathrm{Zn})$ on the optimization of mass yield response of struvite. The crystalline solid product was then characterized using the XRPD Rietveld method for mineral composition and SEM-EDX for morphology and chemical element analysis.

\section{MATERIALS AND METHODS}

\section{Preparation of Crystal-Forming Solution}

The supersaturated solutions for the experiments were prepared by diluting the powder of $\mathrm{MgCl}_{2} \cdot 6 \mathrm{H}_{2} \mathrm{O}$ and $\mathrm{NH}_{4} \mathrm{H}_{2} \mathrm{PO}_{4}$ with analytical grade chemicals (Merck \& Co.), without further purification. In this way, both powder crystals were separately dissolved in a double-distilled water to provide the equimolar of $0.25 \mathrm{M}$ for each ion $\mathrm{Mg}^{2+}, \mathrm{NH}^{4+}$, and $\mathrm{PO}_{4}^{-3}$. The $\mathrm{pH}$ of both solutions was adjusted to be 6.5 by adding $0.5 \mathrm{~N} \mathrm{KOH}$ solution. $\mathrm{Cu}^{2+}, \mathrm{Pb}^{2+}$ and $\mathrm{Zn}^{2+}$ stock solution was prepared by dissolving a specified mass of the corresponding $\mathrm{CuCl}_{2}, \mathrm{PbCl}_{2}$, and $\mathrm{ZnCl}_{2}$ in deionized water. Accordingly, the solution containing 0,10 and $100 \mathrm{ppm}$ of those metals was subsequently diluted into the stock standard of the $\mathrm{MgCl}_{2} \cdot 6 \mathrm{H}_{2} \mathrm{O}$ solution. All solutions were then mixed in a $500 \mathrm{ml}$-glass beaker and stirred at $200 \mathrm{rpm}$ and $\mathrm{pH}$ change was monitored by an Orion SA520 pH meter with a gel epoxy probe. The experiments for struvite crystallization was conducted by the gravitational settling process at ambient temperature. The precipitate was then obtained by filtering off in a paper (Schleicher \& Schuell no. 604), washed with distilled water, and dried directly on the paper at room temperature. The time required the precipitation and filtration of struvite were about 90 minutes. The mass of dried precipitate was weighed using Sartorius weigh-scale.

\section{MATERIALS}

Scanning electron microscopy (SEM) (JEOL JSM 5200) and energy dispersive X-ray spectroscopy (EDX) were used to examine the precipitate for recovering the ion-metal particles on the surface of struvite mineral. In this way, the dried precipitates with different particle sizes below 100 $\mu \mathrm{m}$ were previously embedded in epoxy on an Alsample holder and sputtered with carbon for SEM/ EDX analysis.

Phase identification of the precipitate was conducted by X-ray powder diffraction (XRPD) method through the data obtained from the Bragg-Brentano diffractometer (Philips 1830/40) measurement. The scan parameters $\left(5-85^{\circ} 2 \mathrm{q}\right.$, 0.020 steps, $15 \mathrm{~s} / \mathrm{step}$ ) were set-up for recording XRPD data of the sample. A PC-based searchmatch program (MATCH software) was initially employed for identifying candidate crystalline phases, which was subsequently verified by the Rietveld method available in the program ${ }^{13}, 14,15$. The refined values of the cell parameters were used to calculate (wt. \%) levels of mineralogical phases, which were performed by the program ${ }^{16}$.

\section{Experimental Design and Optimization of Parameters}

In this present study, the input variables $\left(\mathrm{Cu}^{2+}, \mathrm{Pb}^{2+}, \mathrm{Zn}^{2+}\right.$ concentrations $)$ and the yield response of the optimum mass $(\mathrm{mg})$ was investigated by SRM and are given in Table. 1. A multiple regression data analysis was conducted by the statistical v. 6 software packages (StatSoft, Tulsa, OK, USA). The optimum values of the selected input variables were found by solving the regression equation and also by examining the response surface contour plots using equation. 3

$$
Y=\beta_{o}+\sum_{j=1}^{k} \beta_{j} X_{j}+\sum \sum_{i<j} \beta_{i j} X_{i} X_{j}+\sum_{j=1}^{k} \beta_{i j} X_{j}^{2}+\varepsilon
$$


where $\mathrm{Y}$ is the estimated response; $b_{0}, b_{i}$, $b_{\mathrm{ij}}$ and $b_{i \mathrm{ij}}$ constant coefficients; $X_{i}$ and $X_{j}$ are the coded independent variables or factors; $e$ is random error.

\section{RESULTS AND DISCUSSION}

\section{Properties of the Solid Precipitate}

The corresponding solids were then subjected to the XRPD Rietveld method as given in Fig. 1a. The crystals are primarily composed of struvite and sylvite $(\mathrm{KCl})$. Upon the quantitative Rietveld analyses, struvite was precipitated in the wastewater streams as the major mineral (about 99 wt.\%) with a small amount of sylvite (<0.5 wt.\%). Although all data are not shown, obviously, the presence of three metal ions made unchanged the mineral composition of the precipitates (only $50 \mathrm{ppm}$ of $\mathrm{Cu}, \mathrm{Pb}$, and $\mathrm{Zn}$ is shown in Fig. 1b). Fig. 2 shows the SEM image of the crystals obtained exhibiting aggregate formations of irregular prismatic-like crystalline of struvite. This formation was also confirmed again by EDX analysis in Fig. 2, showing the chemical elements of $\mathrm{Mg}, \mathrm{O}$, and $\mathrm{P}$ corresponds to struvite composition. Moreover, the uptake of $\mathrm{Cu}^{2+}$ on the struvite surface was indicated by the element of $\mathrm{Cu}$ in the EDX spectrum. The similar results of metals ( $\mathrm{Pb}$ and $\mathrm{Zn}$ ) captured on the struvite surface were also observed by SEM/EDX, although the results were not shown in this paper. Accordingly, MAP precipitation demonstrated the recovery of metals and phosphate from the solution. An economic return of this precipitation process has been previously reported for the struvite production in the wastewater ${ }^{17}$. Therefore, this precipitation technology is potentially adapted to yield optimum struvite, which has its capability of heavy metal recovery, and the precipitating product can be used for fertilizer.

Table. 1: Range and level of independent variables

\begin{tabular}{lccc}
\hline Independent variables & $\begin{array}{c}\text { Low } \\
\text { Level }(-1)\end{array}$ & $\begin{array}{c}\text { Range and } \\
\text { Level Center } \\
\text { Level }(0)\end{array}$ & High Level $(+1)$ \\
\hline Concentration $\mathrm{Cu}^{2+}(\mathrm{ppm})$ & 0 & 10 & 100 \\
Concentration $\mathrm{Pb}^{2+}(\mathrm{ppm})$ & 0 & 10 & 100 \\
Concentration $\mathrm{Zn}^{2+}(\mathrm{ppm})$ & 0 & 10 & 100 \\
\hline
\end{tabular}
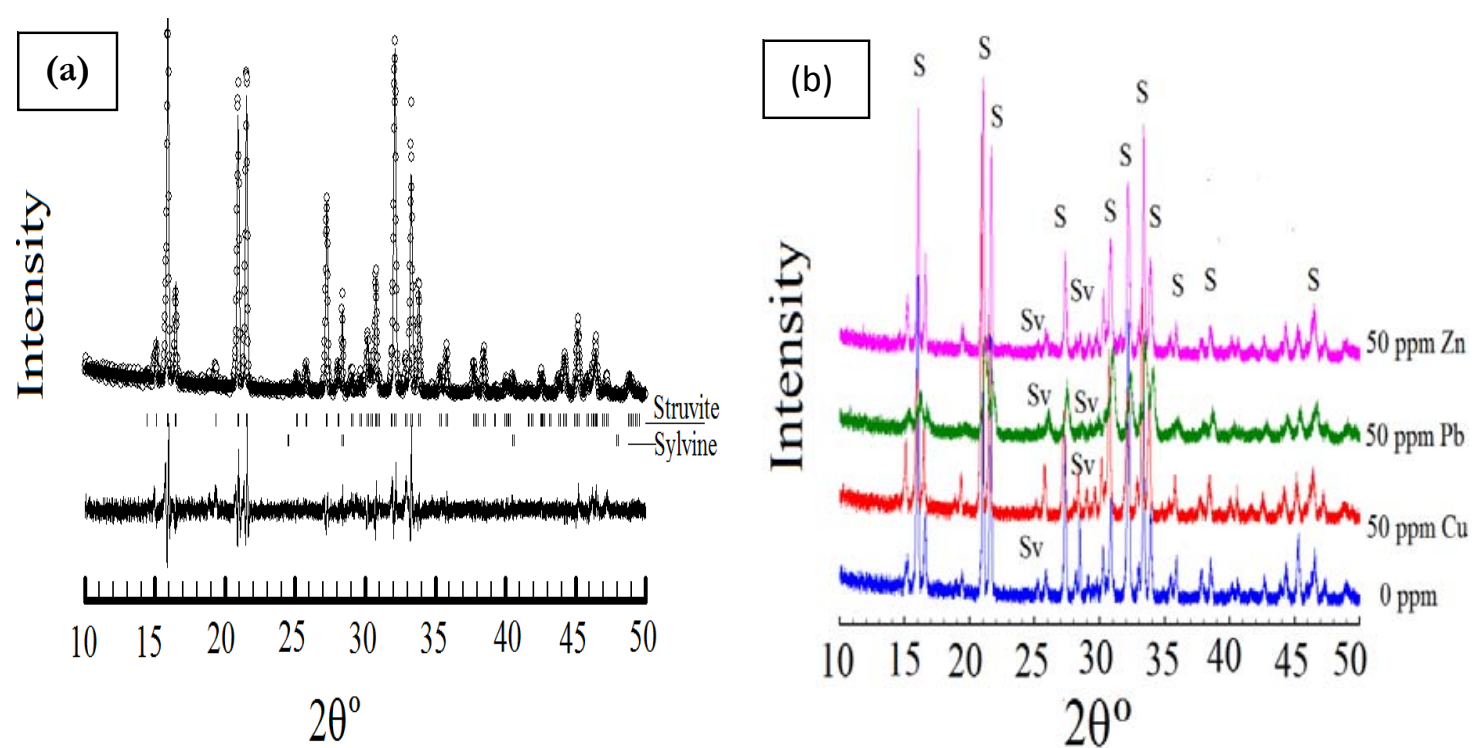

Fig. 1. a) Plot of XRPD Rietveld analysis of the crystals precipitated in the absence of metal ions. b) XRPD patterns of the precipitates with $0 \mathrm{ppm}, 50 \mathrm{ppm} \mathrm{Cu}, 50 \mathrm{ppm} \mathrm{Pb}$, and $50 \mathrm{ppm} \mathrm{Zn}$. The peaks are $\mathrm{S}$ (struvite) and Sv (sylvite) respectively. 

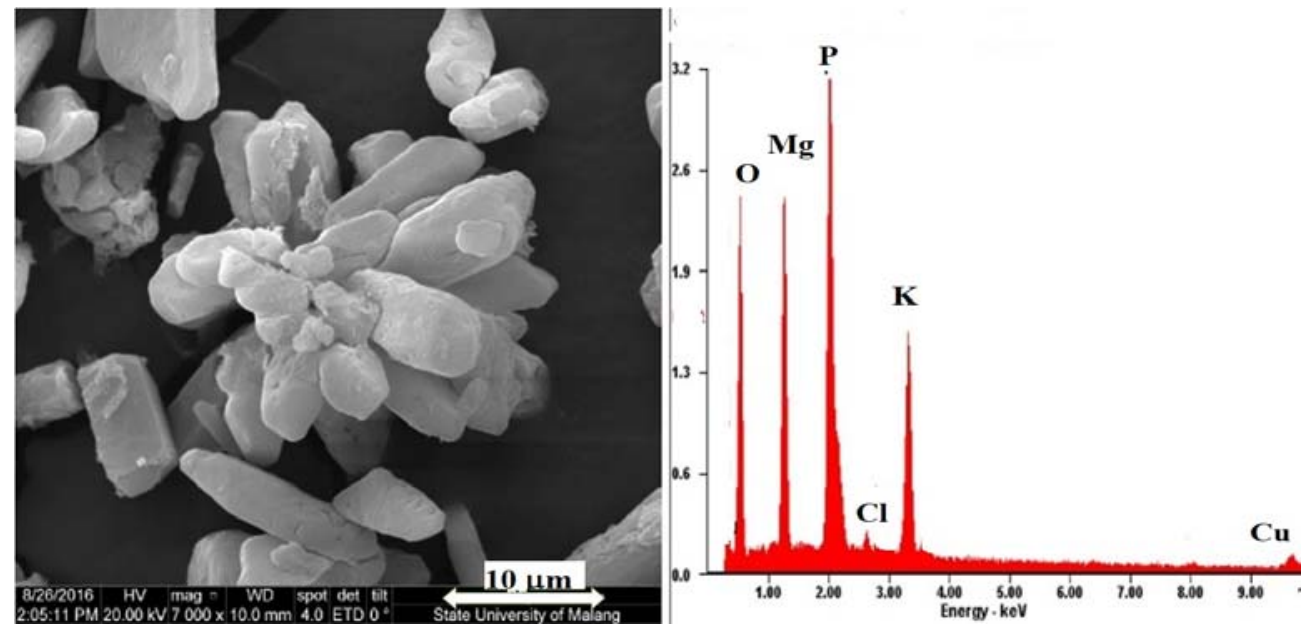

Fig. 2. SEM image of a prism-like shape crystal morphology and EDX spectra obtained from the precipitates at the $30^{\circ} \mathrm{C}$ in the presence of $50 \mathrm{ppm} \mathrm{Cu}$.

\section{Predicted Model and Statistical Analysis}

Model of response variables was optimized using SRM with the input data (Table. 1), which consisted of 3 factorial design $2^{(3)}$ providing $\mathrm{nc}=8 ; \mathrm{ns}=6 ; \mathrm{no}=2$ and run $=16$. Correspondingly, the concentration range of $\mathrm{Cu}^{2+}\left(\mathrm{X}_{1}, 0-100 \mathrm{ppm}\right)$,
$\mathrm{Pb}^{2+}\left(\mathrm{X}_{2}, 0-100 \mathrm{ppm}\right)$ and $\mathrm{Zn}^{2+}\left(\mathrm{X}_{3}, 0-100 \mathrm{ppm}\right)$ was selected for the calculation. Factors and their levels for SRM correspond to the low level $(-1)=0$, high level $(+1)=100$, and the center point $(0)=10$. The whole design of yield response of mass precipitate $(\mathrm{mg})$ is presented in Table. 2.

Table. 2: Design of experiments with independent variables

\begin{tabular}{lcccc}
\hline Run & \multicolumn{3}{c}{$\begin{array}{c}\text { Independent variables } \\
\mathrm{Zn}^{2+}(\mathrm{ppm})\end{array}$} & $\begin{array}{c}\text { Responses } \\
\text { The mass of precipitate }(\mathrm{mg})\end{array}$ \\
\hline 1 & 50.0000 & 50.0000 & 50.0000 & 8.875 \\
2 & 50.0000 & 50.0000 & 100.0000 & 9.36 \\
3 & 50.0000 & 100.0000 & 50.0000 & 8.21 \\
4 & 50.0000 & 100.0000 & 100.0000 & 8.105 \\
5 & 100.0000 & 50.0000 & 50.0000 & 9.105 \\
6 & 100.0000 & 50.0000 & 100.0000 & 9.665 \\
7 & 100.0000 & 100.0000 & 50.0000 & 8.225 \\
8 & 100.0000 & 100.0000 & 100.0000 & 8.825 \\
9 & 32.9552 & 75.0000 & 75.0000 & 8.605 \\
10 & 117.045 & 75.0000 & 75.0000 & 9.525 \\
11 & 75.0000 & 32.9552 & 75.0000 & 9.445 \\
12 & 75.0000 & 117.045 & 75.0000 & 8.01 \\
13 & 75.0000 & 75.0000 & 32.9552 & 9.075 \\
14 & 75.0000 & 75.0000 & 117.045 & 9.515 \\
15 & 75.0000 & 75.0000 & 75.0000 & 8.26 \\
16 & 75.0000 & 75.0000 & 75.0000 & 8.26 \\
\hline
\end{tabular}

Regression analysis of the mathematical model for the optimization of independent variables was fitted to the polynomial Eq. 3, and the adjusted model obtained for struvite production
(Y) can be expressed as Eq.(4).

$Y=14.56481-0.05912 X_{1}+0.00035 X_{1}^{2}-0.03652$ $X_{2}+0.00016 X_{2}^{2}-0.06896 X_{3}+0.00048 X_{3}^{2}+$ $0.00004 X_{1} X_{2}+0.00016 X_{1} X_{3}-0.00011 X_{2} X_{3}^{3}(4)$ 
Analysis of variance (ANOVA) was performed for determining the significance of the model given in Table. 3. The function of more significant variables obviously fits with the quadratic regression model, because the calculated coefficient of determination $\left(\mathrm{R}^{2}\right)$ was quite high (0.982). Moreover, the proposed model is considered statistically significant, according to the
$F$-test with $95 \%$ of confidence. Here $F$-value is defined as the ratio between MSF (mean squares of the factor) of the MSE (mean squares of error). Correspondingly the $F$-value of 86.362041 is much greater than the value of $F$-table (4.1) confirming that the model is significant at $95 \%$ of confidence. Only $1.8 \%$ of the total variation did not fit the model.

Table. 3: ANOVA analyses of the yield response of crystalline mass

\begin{tabular}{lcccccr}
\hline Source & $\begin{array}{c}\text { Sum of } \\
\text { squares (SS) }\end{array}$ & $\begin{array}{c}\text { Degree of } \\
\text { freedom (DF) }\end{array}$ & $\begin{array}{c}\text { Mean } \\
\text { Square(MS) }\end{array}$ & F-value & F-table & $R^{2}$ \\
\hline S.S. Regression & 5.141284 & 9 & 5.141284 & 86.362041 & 4.1 & 0.982 \\
S.S. Error & 0.357191 & 6 & 0.059532 & & \\
S.S. Total & 5.498475 & 15 & & & \\
\hline
\end{tabular}

The experimental results were also analysed in chart Pareto (Fig. 3). Upon the analysis, $p$-value less than 0.05 is considered to have an insignificant effect contributed to the response. On the basis of the results given in Fig. 4, it can be seen that concentration of $\mathrm{Pb}^{2+}\left(\mathrm{X}_{2}\right)$ has major linear $(\mathrm{L})$ effect for controlling struvite production, followed by concentration $(\mathrm{L})$ of $\mathrm{Cu}^{2+}\left(\mathrm{X}_{1}\right)$ and $\mathrm{Zn}^{2+}\left(\mathrm{X}_{3}\right)$; and their quadratic effects $(Q)$ for concentrations of $Z n$ $\left(X_{3}\right)^{2} ; \mathrm{Cu}^{2+}\left(X_{1}\right)^{2}$ and $\mathrm{Pb}^{2+}\left(X_{2}\right)^{2}$. However, the quadratic effect of concentration of $\mathrm{Pb}^{2+}\left(\mathrm{X}_{2}\right)^{2}$ can be ignored because they provide insignificant factor on the yield response of struvite precipitated.

\section{Optimization of Independent Variables for the Optimum Struvite Production}

The graphical results of interactive independent and dependent variables are depicted by $3 D$ and $2 D$ contour plots, which enable to determine the optimum recovery of struvite (mass in mg) (Figs. 4-6). Different forms of the contour plots indicate the different interactive effects,

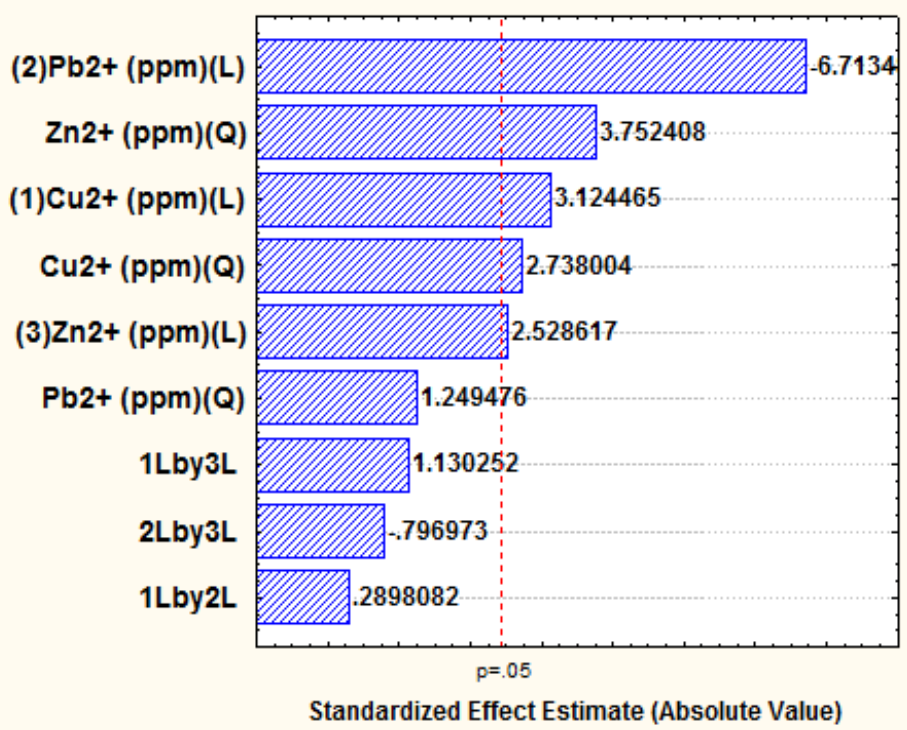

Fig. 3. Pareto chart of optimization for independent variables on the yield response of struvite production. (L) is the linear and $(Q)$ is the quadratic interaction of variables. 
where the significant interactions between the variables are shown in an elliptical contour plot. In contrast, a circular contour plot shows the insignificant interactive effects. Fig. 4 presents the interaction between concentrations of $\mathrm{Cu}^{2+}$ and $\mathrm{Pb}^{2+}$ for the yield of struvite. As expected, the increased yield of struvite occurred at the highest concentration of $\mathrm{Cu}^{2+}$. However, the increased concentration of $\mathrm{Pb}^{2+}$ in the solution made the reduced production of struvite. Additionally, Fig. 5 presents the interactive effects of $\mathrm{Cu}^{2+}$ and $\mathrm{Zn}^{2+}$ concentrations on the yield of struvite. When increasing the concentrations of $\mathrm{Cu}^{2+}$ and $\mathrm{Zn}^{2+}$ were reached at $70 \mathrm{ppm}$, the high amount of struvite could be produced. In contrast, the concentrations of $\mathrm{Cu}^{2+}$ and $\mathrm{Zn}^{2+}$ increased to above $70 \mathrm{ppm}$ leading to the reduced production of struvite. Therefore, both $\mathrm{Cu}^{2+}$ and $\mathrm{Zn}^{2+}$ have significant effects on retarding the struvite production. Conversely, the effect of $\mathrm{Pb}^{2+}$ on the struvite production was more apparent than $\mathrm{Cu}^{2+}$ and $\mathrm{Zn}^{2+}$ removal.
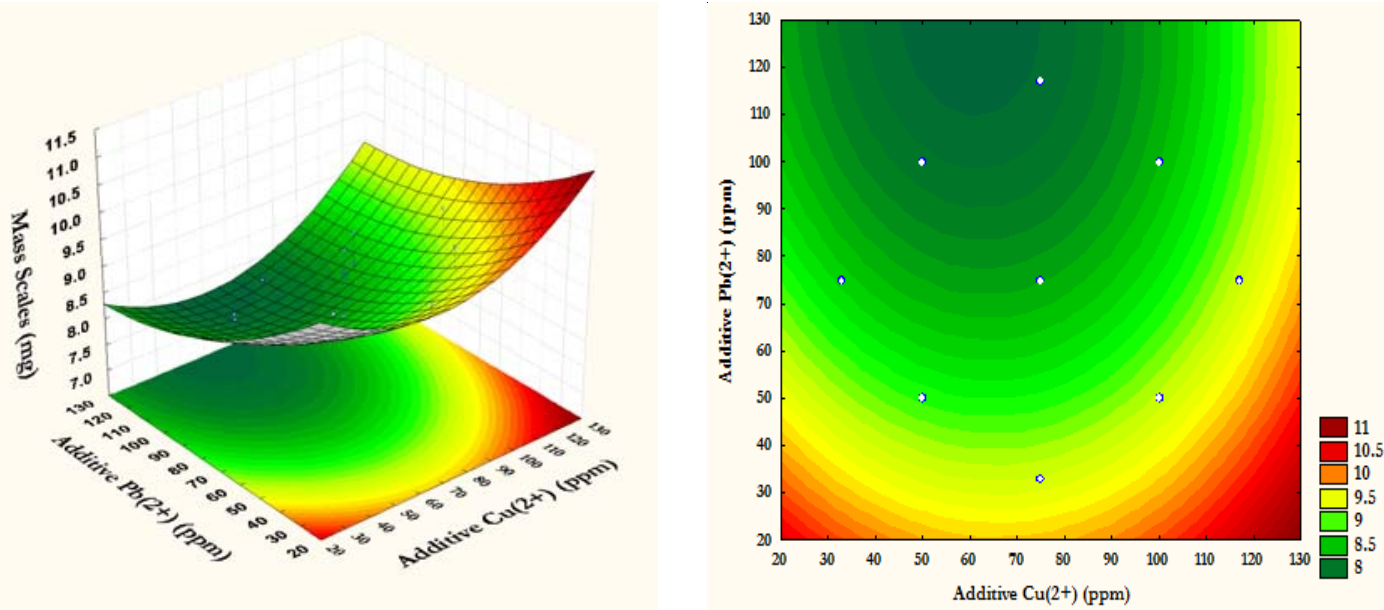

Fig. 4. Response surface contours for mass scales production showing effects of interactive concentrations of $\mathrm{Cu}^{2+}$ and $\mathrm{Pb}^{2+}$.
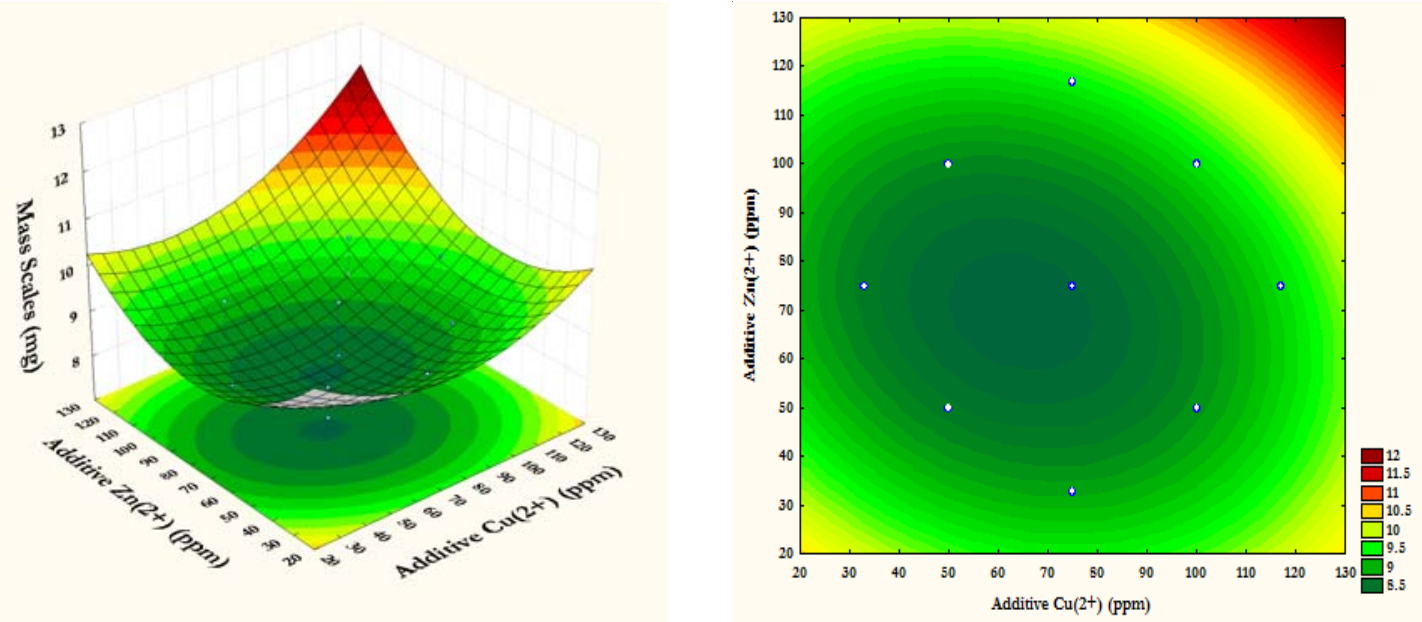

Fig. 5. Response surface contours for mass scales production showing effects of interactive concentrations of $\mathrm{Cu}^{2+}$ and $\mathrm{Zn}^{2+}$. 
Furthermore, the interaction between the concentration of $\mathrm{Pb}^{2+}$ and concentration of $\mathrm{Zn}^{2+}$ on the yield of the mass of precipitate are shown in Fig. 6. Apparently, the increase of concentrations of $\mathrm{Pb}^{2+}$ from 50 to $100 \mathrm{ppm}$ made a decrease in the struvite production. Conversely, the more concentrations of $\mathrm{Zn}^{2+}$ available in the solution could be recovered at the increase of struvite production. Of the three metal ions, $\mathrm{Zn}^{2+}$ could be the most insignificant effect in promoting crystal growth of struvite. This result was in close agreement with the previous reports in the literature ${ }^{8,17}$.

Further, the use of the statistical v.6 software enabled to obtain the response surfaces which in turn allow the determination of optimum concentration from $2 \mathrm{D}$ and $3 \mathrm{D}$ contours. It can be concluded from Figs. 4-6 that the optimum mass of struvite was quite effective to trap metals and the computed results are shown in Table. 4.

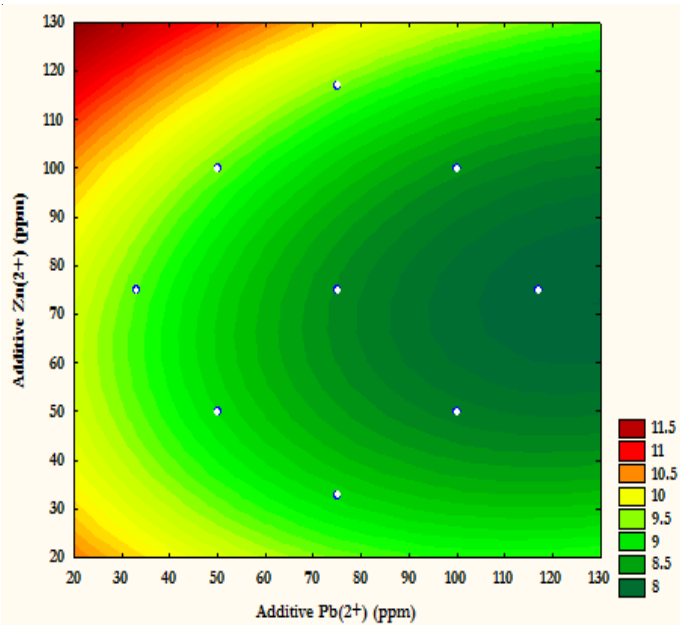

Fig. 6. Response surface contours for mass scales production showing effects of interactive concentrations of $\mathrm{Pb}^{2+}$ and $\mathrm{Zn}^{2+}$

Table. 4: Optimum the mass of struvite $(\mathrm{mg})$

\begin{tabular}{lcc} 
Factor & $\begin{array}{c}\text { Optimum } \\
\text { concentration }(\mathrm{ppm})\end{array}$ & $\begin{array}{c}\text { Optimum mass of } \\
\text { precipitate }(\mathrm{mg})\end{array}$ \\
\hline Concentration $\mathrm{Cu}^{2+}(\mathrm{ppm})$ & 59.4564 & \\
Concentration $\mathrm{Pb}^{2+}(\mathrm{ppm})$ & 70.7930 & 8.342 \\
Concentration $\mathrm{Zn}^{2+}(\mathrm{ppm})$ & 77.2114 &
\end{tabular}

\section{Validation of the predicted value for the optimal variables}

To validate the predicted value was performed by conducting experimental run with the optimum values of the process variables. Table. 4 presents the optimum yield of struvite calculated using the input data of each concentration of $\mathrm{Cu}^{2+}$ (59.4564 ppm), $\mathrm{Pb}^{2+}$ (70.7930 ppm) and $\mathrm{Zn}^{2+}$ (77.2114 ppm), and hence providing $8.342 \mathrm{mg}$ of the mass of precipitate. Referring to the experimental results is shown in Table 5 , the mass precipitated at these concentrations was reached at $8.562 \mathrm{mg}$. Here the calculated \% error in the mass of precipitate response was $2.56 \%$. This result implies that the calculated response of struvite production has an accuracy of $97.44 \%$.

It is noteworthy that the induced MAP precipitation through the formation of struvite from the synthetic wastewater offers an opportunity to recover nutrients and heavy metals. This method produced struvite which can be potential as a 
slow-release fertilizer. It is not only employed for sustainable recovery of wastewater phosphorus, but also for absorbing metals and organics which can enhance the property of fertilizer product with environmentally friendly. Moreover, a series of batch experiments had been conducted to assay the effect of heavy metals on the optimal struvite product. It demonstrates that the high concentration of metal ions in the range of 50-80 ppm could be recovered with the optimum struvite crystals produced. Nevertheless, remaining works related to the agronomic bioavailability of struvite should be performed in a greenhouse experiment in order to be admitted as a synthetic plant fertilizer. Agronomic assays showed that struvite found in this study is similar to that of synthesis ammonium phosphate fertilizers.

Table. 5: The predicted and experimental value of the response at the optimum level of metal concentration

Optimum variables
Optimum

Result (mg) Experimental \% Relative error
Result (mg)

\begin{tabular}{lllll}
\hline Concentration $\mathrm{Cu}^{2+}(\mathrm{ppm})$ & 59.4564 & & & \\
Concentration $\mathrm{Pb}^{2+}(\mathrm{ppm})$ & 70.7930 & 8.342 & & $2.56 \%$ \\
Concentration $\mathrm{Zn}^{2+}(\mathrm{ppm})$ & 77.2114 & & & \\
\hline
\end{tabular}

Relative error $(\%)=[($ Experimental result- Optimum result by SRM $) /$ Experimental result $] \times 100 \%$.

In terms of the proposed study, $\mathrm{pH}$ of 6.5 was found to be a desirable value for removing heavy metal from wastewater by MAP precipitation ${ }^{18,19}$, while changes in temperature may have no influence on the struvite production. In wastewater systems containing heavy metals with other inorganic substance, the presence of $\mathrm{K}^{+}$in the solution may have no significant effect on the efficiency. However, the presence of $\mathrm{Ca}^{2+}$ may decrease the percentage of $\mathrm{Mg}^{2+}$ and $\mathrm{NH}_{4}{ }^{+}$removal. Additionally, the presence of metal ions in the solution resulted in a reduction of mass and the crystal size of struvite 20,21 .

In general, the induced MAP precipitation was applied in this study offering various benefits such as their low and rapid processes, simple operation and control, flexibility to change of temperature. Unlike in biological systems, the precipitation can facilitate variable input loads and flow such as seasonal flows and complex discharge. Whenever it is needed, a chemical plant for wastewater treatment could be easily developed. Besides, the treatment system developed involves only a lower space and installation cost. Their advantages, however, are outweighed by a number of disadvantages such as their high operational costs due to the chemicals required, high-energy consumption and handling costs for sludge disposal. Nevertheless, in reducing additional cost of chemicals for the induced MAP precipitation, an industrial-grade (IG) $\mathrm{MgO}$ and $\mathrm{Mg}(\mathrm{OH})_{2}$ has been proposed as the low-cost magnesium sources, which can result in struvite to be prevalent in the precipitate $^{21}$.

\section{CONCLUSIONS}

SRM optimization of variable concentrations of heavy metals in the wastewater provided that the availability of $\mathrm{Pb}^{2+}$ has the significant effect on the mass yield of struvite during precipitation. The optimum result of the mass response scale (8.342 mg) was reached at the concentration of $\mathrm{Cu}^{2+}$ of $59.4564 \mathrm{ppm}, \mathrm{Pb}^{2+}$ of $70.7930 \mathrm{ppm}, \mathrm{Zn}^{2+}$ of 77.2114 ppm, respectively. Accordingly, a good achievement of modelling and optimization of struvite precipitation for heavy metal recovery was presented in this paper. The influence of selected parameters and thus model validation with insignificance parameters could be confirmed. Finally, an easy, simple, and cost-effective precipitation method could be implemented for wastewater treatment containing heavy metals, whereas the induced MAP precipitation provided the valuable fertilizer product rich in phosphorous.

\section{ACKNOWLEDGMENTS}

The authors express their gratitude to the University of Pembangunan National "Veteran" Surabaya, East Java, Indonesia for providing this $\mathrm{PhD}$ research project. 


\section{REFERENCES}

1. Doyle, J.D.; Parsons S.A. Water Res., 2002, 36, 3925-3940

2. Capdeviellea, A.; Sykorová, E.; Biscans, B.; Bélinea, F.; Daumer, M-L. J. Hazard. Mater., 2013, 244-245, 357-369

3. Doyle, J.D.; Oldring, K.; Churchley, J.; Price C.; Parsons, S.A. J. Environ. Eng.-ASCE., 2003, 129, 419-426

4. Barakat, M.A. Arabian J. Chem. 2011, 4, 361-377

5. Ge, F.; Li, M-M.; Ye, H.; Zhao, B-X. J. Hazard. Mater., 2012, 211-212, 366- 372

6. Ronteltap. M.; Maurer, M.; Gujer, W. Water Res., 2007, 41, 977-984

7. Wilsenach, J.; Schuurbiers C.; Van Loosdrecht, M.C.M. Water Res., 2007, 41, 458-466

8. Muryanto, S.; Bayuseno, A.P. Powder Technol., 2014, 253, 602-607

9. Stratful, I.; Scrimshaw, M.D.; Lester, J.N. Water Environ. Res., 2004, 76, 437-4199

10. Saidou, H.; Atef, K.; Sami, B.M.; Mohamed, B.A. Open J. Inorg. Chem., 2015, 5, 41-51

11. Suzuki, K.; Tanaka, Y.; Kuroda, K.; Hanajima, D.; Fukumoto, Y. Bioresour. Technol., 2005, 96, 1544-1550

12. Demeestere, K.; Smet, E.; Van Langenhove,
H.; Galbacs, Z. Environ. Technol., 2001, 22, 1414-1428

13. Rietveld, H.M. J. Appl. Crystallogr., 1969, 2, 65-71

14. Rodriguez-Carvajal, J. Program Fullprof 2k, version 3.30, Laboratoire Leon Brillouin, France, June 2005.

15. Caglioti, G.; Paoletti, A.; Ricci, F.P. Nucl. Instrum., 1958, 35, 223-228

16. Mahieux, P.-Y.; Aubert, J.-E.; Cyr, M.; Coutand, M.; Husson, B. Waste Manage., 2010, 30, 378-388

17. Shalaby, M.S.; El-Rafie, Sh.; Hamzaoui, A.H.; M'nif, A. Chem. Biochem. Eng. Q., 2015, 29, 35-46

18. El-Gawad, H.A.; Kattab, I.A.; Mahdy, A.N.; Moselhy, H.; Ibrahim, O.A. RJPBCS., 2017, 8,1366-1380

19. Wang, H.; Wang, X-J.; Wang, W-S.; Yan, XB.; Xia, P.; Chen, J.; Zhao. J-F. J. Chem. Technol. Biotechnol., 2016, 91, 3045-3052

20. Ivanetsa, A.I.; Kitikova, N.V.; Shashkova, I. L; Oleksiienko, O.V.; Levchuk. I.; Sillanpaa, M.; JECE., 2014, 2, 981-987

21. Peng, C.; Chai, L-Y.; Tang, C-J.; Min Ali, X-B. M.; Song, Y-X.; Qi, W-M. J. Chem. Technol. Biotechnol., 2017, 92, 325-333. 